\title{
UPAYA MEMBANGUN LOYALITAS KONSUMEN MELALUI PENDEKATAN KUALITATIF PADA KUALITAS PRODUK DAN KUALITAS PELAYANAN DI FAKULTAS EKONOMI UMN AL WASHLIYAH MEDAN T.A 2013/2014
}

\author{
Yayuk Yuliana \\ Universitas Muslim Nusantara Al -Washliyah Medan \\ J1. Garu II No.93 Medan \\ Email: yayuk.yuliana14@gmail.com
}

\begin{abstract}
Abstrak
Penelitian ini membahas upaya mengelola loyalitas pelanggan melalui strategi kualitas produk dan kualitas pelayanan. Metode yang digunakan adalah kualitatif berdasarkan penelitian deskriptif yang telah dilakukan pada Mahasiswa Universitas Muslim Nusantara Al Washliyah, Fakultas Ekonomi Manajemen. Sampel yang digunakan sebanyak 50 responden pengguna atau konsumen IM3 indosat. Hasil penelitian secara deskirptif bahwa kualitas produk berpengaruh secara positif pada loyalitas pelanggan signifikansi adalah 0,010,<0,05. Pada penelitian ini kualitas pelayanan berpengaruh secara positif signifikansi adalah 0,011, <0,05 pada loyalitas pelanggan. Hasil analisis kualitatif bahwa loyalitas konsumen mempunyai konsekuensi motivasi dan perilaku. Pertama motivasi untuk mencari informasi mengenai produk. Motivasi pencarian informasi merupakan fungsi dari persepsi konsumen dari manfaat dan biaya aktivitas mencari alternatif. Manfaat pencarian akan berkurang apabila konsumen memiliki sikap relative sangat positif dan mereka dapat melakukan pembelian ulang beberapa kali. Biaya pencarian bisa berupa waktu, biaya, dan ketidaknyamanan fisik serta psikologis berkaitan dengan aktivitas mencari pemasok, produk atau merek alternative. Loyalitas pelanggan berdampak pada perilaku gethok tular (word-of-mouth behavior) terutama bila konsumen merasakan pengalaman emosional yang signifikan.
\end{abstract}

Kata Kunci : loyalitas, kualitas produk, kualitas pelayanan

\begin{abstract}
This research discusses the effort to manage customer loyalty through product quality strategy and service quality. The method used is qualitative based on descriptive research that has been done on Muslim University Students Nusantara Al Washliyah, Faculty of Management Economics. The sample used is 50 respondent users or IM3 indosat consumer. The result of the research is descriptive that product quality positively influence on customer loyalty significance is 0,010, <0,05. In this study the quality of service positively influence the significance is 0.011, <0.05 on customer loyalty. The results of qualitative analysis that consumer loyalty has consequences of motivation and behavior. First the motivation to find information about the product. Motivation of information search is a function of consumer perception of benefit and expense of activity seek alternative. The benefits of search will be reduced if the consumer has a relatively positive attitude and they can repeat the purchase several times. Search costs can be time, cost, and physical and psychological discomfort related to activities looking for suppliers, products or alternative brands. Customer loyalty affects word-of-mouth behavior, especially when consumers experience significant emotional experiences.
\end{abstract}

Keywords: loyalty, product quality, service quality 


\section{PENDAHULUAN}

Perusahaan yang terdepan adalah perusahaan yang dapat beradaptasi dengan perkembangan teknologi yang ada dan memanfaatkan peluang-peluang yang ada, serta mereka yang dapat melakukan inovasi terhadap produknya agar dapat tercapainya kepuasan dan loyalitas pelanggan.

Konsumen saat ini dihadapkan kepada berbagai pilihan produk maupun jasa yang dapat mereka beli. Hal ini berdampak terhadap tuntutan yang lebih besar dari konsumen kepada perusahaan agar terus memberikan produk yang dapat diterima, karena bila tidak, konsumen akan dengan mudah beralih kepada pesaing.

Loyalitas pelanggan sangat penting artinya bagi perusahaan yang menjaga kelangsungn usahanya maupun kelangsungan kegiatan usahanya. Pelanggan yang setia adalah mereka yang sangat puas dengan produk dan pelayanan tertentu, sehingga mempunyai antusiasme untuk memperkenalkan kepada siapapun yang mereka kenal. Selanjutnya pada tahap berikutnya pelanggan yang loyal tersebut akan memperluas "kesetiaan" mereka pada produk-produk lain buatan produsen yang sama. Kotller (2009) menyatakan bahwa loyalitas tinggi adalah pelanggan yang melakukan pembelian dengan prosentasi meningkat pada perusahaan tertentu daripada perusahaan lain. Dilihat dari kualitas produk, kualitas mencerminkan kemampuan produk untuk menjalankan tugasnya yang mencakup daya tahan, kehandalan, kemajuan, kekuatan, kemudahan dalam pengemasan dan reparasi produk dan ciri-ciri lainnya (Kotler dan Amstrong 2009).

Dari segi kualitas pelayanan, penilaian konsumen tentang kehandalan dan superioritas pelayanan secara keseluruhan (Zeithml, 2009). Konsumen akan membuat perbandingan antara yang mereka berikan dengan apa yang mereka dapat (Bloemer et al. 1998 dalam Karsono 2007). Menurut Berry et al. (1988), kualitas jasa menjadi senjata kompetitif yang paling kuat oleh banyak organisasi dalam hal pelayanan. Manajer organisasi bekerja keras untuk memelihara kualitas pelayanan sebagai upaya menciptakan loyalitas pelanggan (Zeithaml, 1996), oleh karena itu perusahaan yang ingin sukses dalam jangka panjang dan mencapai pangsa pasar ditentukan oleh kemampuannya untuk memperluas dan memelihara loyalitas pelanggan

Loyalitas menjadi tujuan utama dibanyak perusahaan karena berhubungan dengan kelangsungan hidup suatu merek atau bahkan perusahaan itu sendiri. Loyalitas didefinisikan sebagai komitmen konsumen untuk melakukan bisnis dengan perusahaan, membeli produk atau jasa perusahaan tersebut secara berulang, dan pada saat yang bersamaan merekomendasikan produk dan atau jasa tersebut kepada teman atau rekannya (Mcllroy \& Barnett, 2000). Dari definisi tersebut terdapat kata kunci yang membedakan dengan pembelian berulang yang disebut inertia, yakni komitmen. Inertia adalah pembelian berulang namun tidak diikuti dengan adanya komitmen dengan produk atau jasa (Assael, 1998. Pada kasus inertia, karena tidak adanya komitmen, maka seorang konsumen 
akan mudah berpindah ke produk dan atau jasa yang lain manakala konsumen tersebut punya waktu untuk memproses informasi secara mendalam dan produk yang biasa dibeli mengalami lack distribusi (kelangkaan produk dipasar). Loyalitas bermakna bahwa pembelian berulang tersebut diikuti dengan komitmen terhadap produk dan atau jasa lain. Loyalitas terjadi ketika konsumen merasakan bahwa kebutuhannya terpenuhi secara sangat baik oleh produk dan atau jasa tersebut dibandingkan dengan yang lain.

Loyalitas mempunyai perilaku pembelian ulang, yang secara psikologis berarti kesetiaan pada suatu merek tunggal. Usaha untuk memahami kesetiaan pada merek tunggal dapat dilakukan dengan cara (Dharmmesta, 1999):

a. Struktur keyakinan (kognitif) Informasi merek yang dipegang oleh konsumen (keyakinan konsumen) harus menunjuk pada merek fokal yang dianggap superior dalam persaingan. Pada kondisi ini basis informasi menjadi sandaran utama, jadi loyalitas didasarkan pada kognisi.

b. Struktur sikap (afektif) Tingkat kesukaan konsumen harus lebih tinggi dari merek saingan, sehingga terdapat preferensi afektif yang jelas pada merek fokal. Dasar utama dari pendekatan ini adalah bahwa sikap merupakan fungsi dari periode sebelumnya dan periode pasca konsumsi. Loyalitas ini berarti bahwa loyalitas masuk dalam benak konsumen sebagai efek bukan lagi sebagai kognisi semata, sehingga loyalitas tahap ini lebih susah berubah dibandingkan pada struktur kognitif.

c. Struktur niat (konatif) Konsumen harus mempunyai niat untuk membeli merek fokal, bukanya merek lain, ketika keputusan beli dilakukan. Tahapan ini sudah melampaui afek, sehingga terbentuklah loyalitas yang mencakup komitmen mendalam untuk melakukan pembelian.

Pengertian Lain Loyalitas Pelanggan menurut Bernard $T$ Widjaja (2009) adalah komitmen mendalam untuk membeli produk dan atau jasa secara berkesinambungan dan tidak sensitif terhadap perubahan situasi yang menyebabkan perpindahannya. Oliver dalam Chauduri dan Holbrook (2001) mendefinisikan loyalitas pelanggan sebagai sebuah komitmen yang kuat untuk membeli ulang terhadap suatu produk atau jasa secara konsisten di waktu yang akan datang. Dengan demikian menyebabkan perulangan pada merek yang sama atau membeli merek yang sama. Loyalitas pelanggan mempunyai dampak yang luar biasa pada perusahaan. Sebagai konsekuensinya mempertinggi loyalitas pelanggan pada perusahaan jasa akan meningkatkan pendapatan, mengurangi biaya menambah konsumen dan biaya dalam memberikan profitabilitas.

Produk adalah semua yang bisa ditawarkan dipasar untuk mendapatkan perhatian, permintaan, pemakaian atau konsumsi yang dapat memenuhi keinginan atau kebutuhan konsumen (Tjiptono, 2008).

Di dalam kualitas produk, terdapat 8 (delapan) dimensi, yakni:

1. Kinerja (performance) yang merupakan karakteristik dasar produk. Merupakan karakteristik 
operasi pokok dari produk inti (core product) yang dibeli.

2. Ciri-ciri atau keistimewaan tambahan (features), yaitu karakteristik sekunder atau pelengkap.

3. Kehandalan (reliability), yang merupakan kemungkinan kegagalan produk dalam rencana waktu yang diberikan. Kehandalan yaitu kemungkinan kecil akan mengalami kerusakan atau gagal dipakai.

4. Kesesuaian (Conformance) yang merupakan derajat atau tigkat dimana sebuah barang atau jasa memenuhi penetapan suatu standar. Kesesuaian dengan spesifikasi (conformance to spesification) yaitu sejauh mana karakteristik desain dan operasi produk memenuhi standar-standar yang telah ditetapkan sebelumnya.

5. Daya Tahan (durability), berkaitan dengan berapa lama produk tersebut dapat terus digunakan. Dimensi ini mencakup umur teknis maupun umur ekonomis penggunaan produk.

6. Service Ability, yang merupakan kecepatan dan kemudahan pembetulan dan kemampuan dari jasa individu.

7. Estetika, merupakan daya tarik produk terhadap panca indra.

Kualitas yang dipersepsikan, merupakan kualitas yang diambil dari reputasi penjualnya. Kualitas pelayanan dipandang sebagai salah satu komponen yang perlu diwujudkan oleh perusahaan, karena memiliki pengaruh untuk mendatangkan konsumen baru dan dapat mengurangi kemungkinan pelanggan lama untuk berpindah ke perusahaan lain. Kualitas pelayanan didefinisikan sebagai tingkat keunggulan yang diharapkan dan pengendalian atas tingkat keunggulan tersebut untuk memenuhi keinginan pelanggan (Tjiptono, 2008).

Berdasarkan definisi-definisi yang telah disebutkan, maka kualitas pelayanan dapat diartikan sebagai upaya pemenuhan kebutuhan dan keinginan konsumen serta ketepatan penyampaiannya dalam mengimbangi harapan konsumen. Adapun lima dimensi kualitas pelayanan yang diidentifikasikan oleh Tjiptono (2008) meliputi SERVQUAL (Service Quality), yaitu:

1. Reliability (Keandalan)

Yaitu kemampuan memberikan layanan yang dijanjikan dengan segera, akurat dan memuaskan.

2. Responsiveness (daya tanggap)

Yaitu keinginan perusahaan atau staf untuk membantu konsumen dan memberikan layanan dengan tanggap dan sebaik mungkin.

3. Assurance (jaminan)

Yaitu mencakup pengetahuan, kemampuan, kesopanan, dan sifat dapat dipercaya yang dimiliki para karyawan, bebas dari bahaya resiko atau keragu-raguan.

4. Empathy (empati)

Meliputi kemudahan dalam melakukan hubungan, komunikasi yang baik, perhatian personel, dan memahami kebutuhan para pelanggan.

5. Tangibles (bukti langsung)

Meliputi fasilitas fisik, perlengkapan, pegawai dan sarana komunikasi.

Kualitas pelayanan dibangun atas adanya perbandingn dua faktor utama, yaitu persepsi pelanggan atas layanan yang nyata mereka terima dengan layanan yang sesungguhnya diharapkan. Jika kenyataanya lebih dari yang diharapkan maka layanan 
dapat dikatakan berkualitas dan sebaliknya.

\section{METODE}

Metode kualitatif yang digunakan dalam penelitian ini dengan analisis deskriftif dengan menyebarkan kuisioner sebanyak 50 responden. Metode dalam pengambilan sampel adalah non probability sampling yaitu, teknik pengambilan sampel yang tidak memberi peluang/kesempatan sama bagi setiap unsur atau anggota populasi untuk dipilih menjadi sampel (Sugiyono 2010). Yang menjadi syarat pertimbangan dalam non probailitiy pada penelitian ini adalah mahasiswa Fakultas Ekonomi UMN yang menggunakan produk Operator seluler IM3. Sedangkan teknik pengambilan sampel berupa purposive sampling dengan pembagian berdasarkan program studi yang masih terdaftar sebagai mahasiswa reguler pada fakultas Ekonomi UMN Al-Washliyah Angkatan Tahun 2013/2014. Pengukuran dengan menggunakan Skala Likert.

\section{HASIL DAN PEMBAHASAN}

Pada Uji $t$ dimaksudkan untuk mengetahui seberapa jauh pengaruh satu variabel independen (kualitas produk, kualitas pelayanan) secara individual dalam menerangkan variabel dependen (loyalitas pelanggan). Hasil uji t pada penelitian ini dapat dilihat pada tabel 1.1 .

Tabel 1.Hasil Regresi Untuk Variabel Tergantung Loyalitas Pelanggan Pada Pengguna IM3

\begin{tabular}{|l|c|c|c|}
\hline Variabel & $\begin{array}{c}\text { Koefisie } \\
\text { n Regresi }\end{array}$ & $\mathrm{t}$ & Sig. \\
\hline $\begin{array}{l}\text { Kualitas } \\
\text { Produk }\end{array}$ & 0.378 & $\begin{array}{c}2.69 \\
5\end{array}$ & $\begin{array}{c}0.01 \\
0\end{array}$ \\
\hline
\end{tabular}

\begin{tabular}{|l|c|c|c|}
\hline $\begin{array}{l}\text { Kualitas } \\
\text { Pelayana } \\
\mathrm{n}\end{array}$ & 0.371 & $\begin{array}{c}2.64 \\
8\end{array}$ & $\begin{array}{c}0.01 \\
1\end{array}$ \\
\hline
\end{tabular}

Sumber: Data Primer Diolah

Tabel 1. menunjukkan hasil regresi variabel tergantung loyalitas Pelanggan

a. Variabel Kualitas Produk Ho : $b_{1}=0$ :Kualitas produk tidak berpengaruh positif signifikan terhadap loyalitas pelanggan

Ha : $b_{1}>0=$ Kualitas produk berpengaruh positif signifikan terhadap loyalitas pelanggan Berdasarkan hasil pada Tabel 1. Hasil pengujian dengan SPSS diperoleh untuk variabel kualitas produk diperoleh untuk nilai t hitung 2,695 dan nilai koefisien regresi sebesar 0,378 menerangkan besar kecilnya pengaruh variabel independen (kualitas produk) terhadap variabel dependen (loyalitas pelanggan), dan karena koefisien regresi bertanda positif maka pengaruhnya adalah positif. Pada penelitian ini signifikansi adalah $0,010,<0,05$ maka Ho ditolak atau $\mathrm{Ha}$ diterima. Sehingga dapat disimpulkan bahwa kualitas produk berpengaruh secara positif pada loyalitas pelanggan. Oleh karena itu, hipotesis pertama yang diajukan dalam penelitian ini diterima.

b. Variabel Kualitas Pelayanan Ho $: b_{2}=0:$ Kualitas pelayanan tidak berpengaruh positif signifikan terhadap loyalitas pelanggan

$\mathrm{Ha}: \mathrm{b}_{2}>0=$ Kualitas pelayanan berpengaruh positif signifikan terhadap loyalitas pelanggan

Berdasarkan hasil pada Tabel 1. Hasil pengujian dengan SPSS diperoleh untuk variabel kualitas pelayanan diperoleh untuk nilai $\mathrm{t}$ hitung 2,648 dan nilai koefisien regresi sebesar 0,371 menerangkan 
besar kecilnya pengaruh variabel independen (kualitas pelayanan) terhadap variabel dependen (loyalitas pelanggan), dan karena koefisien regresi bertanda positif maka pengaruhnya adalah positif. Pada penelitian ini signifikansi adalah $0,011,<0,05$ maka Ho ditolak atau Ha diterima. Sehingga dapat disimpulkan bahwa kualitas pelayanan berpengaruh secara positif pada loyalitas pelanggan. Seperti halnya hipotesis pertama, hipotesis kedua yang diajukan dalam penelitian ini juga diterima.

Berdasarkan informasi dari hasil penelitian bahwa seorang konsumen yang memiliki loyalitas memiliki ciri-ciri sebagai berikut yaitu mempunyai perilaku pembelian ulang, yang secara psikologis berarti kesetiaan pada suatu merek tunggal. Usaha memahami kesetiaan pada merek tunggal dapat dilakukan dengan cara (Dharmmesta, 1999):

a. Loyalitas Kognitif

Informasi merek yang dipegang oleh konsumen (keyakinan konsumen) harus menunjuk pada merek fokal yang dianggap superior dalam persaingan. Pada kondisi basis informasi menjadi sandaran utama, jadi loyalitas didasarkan pada kognisi.

b. Loyalitas Afektif

Tingkat kesukaan konsumen harus lebih tinggi dari merek saingan, sehingga terdapat preferensi afektif yang jelas pada merek fokal. Dasar utama dari pendekatan ini adalah bahwa sikap merupakan fungsi dari kognisi (pengharapan) pada periode pra konsumsi yang merupakan fungsi dari periode sebelumnya dan periode pasca konsumsi. Loyalitas ini berarti bahwa loyalitas masuk dalam benak konsumen sebagai afek bukan lagi sebagai kognisi semata, sehingga loyalitas tahap ini lebih susah berubah dibangdingkan pada struktur kognitif.

c. Loyalitas Konatif

Konsumen harus mempunyai niat untuk membeli merek fokal, bukannya merek lain, ketika keputusan beli dilakukan. Tahapan ini sudah melampaui afek, sehingga terbentuklah loyalitas yang mencakup komitmen mendalam untuk melakukan pembelian.

d. Loyalitas Tindakan

Dalam runtutan kontrol tindakan, niat yang diikuti oleh motivasi, merupakan kondisi yang mengarah pada kesiapan bertindak dan pada keinginan untuk mengatasi hambatan dalam mencapai tindakan tersebut. Artinya tindakan merupakan hasil pertemuan dua kondisi tersebut. Dengan kata lain, tindakan yang akan datang sangat didukung oleh pengalaman mencapai sesuatu dan penyelesaian hambatan. Hal ini menunjukkan bagaimana loyalitas dapat menjadi kenyataan, yaitu pertama-tama sebagai loyalitas kognitif, afektif dan konatif, dan akhirnya loyalitas tindakan.

Proses seorang konsumen menjadi seorang konsumen yang loyal terhadap perusahaan terbentuk melalui beberapa tahap. Menurut pandangan Niegell Hill (dalam Susilawati, 2007:18). Loyalitas konsumen terbagi menjadi enam tahapan yaitu :

a) Suspect

Meliputi semua yang diyakini akan membeli atau membutuhkan barang atau jasa, tetapi belum 
memiliki informasi tentang barang atau jasa perusahaan.

b) Prospect

Adalah orang-orang yang memiliki kebutuhan akan jasa tertentu dan mempunyai kemampuan untuk membelinya. Pada tahap ini, meskipun mereka belum melakukan pembelian tetapi telah mengetahui keberadaan perusahaan dan barang yang ditawakan melalui rekomendasi pihak lain.

c) Customer

Pada tahap ini, konsumen sudah melakukan hubungan transaksi dengan perusahaan, tetapi tidak mempunyai perasaan positif terhadap perusahaan, loyalitas pada tahap ini belum terlihat

\section{d) Client}

Meliputi semua konsumen yang telah membeli barang atau jasa yang dibutuhkan dan ditawarkan perusahaan secara teratur, hubungan ini berlangsung lama dan mereka telah memiliki hubungan kerjasama yang baik.

b. Advocates

Pada tahap ini, konsumen secara aktif mendukung perusahaan dengan memberikan rekomendasi kepada orang lain agar mau membeli barang atau jasa di perusahaan tersebut.

\section{c. Partners}

Kemudian pada tahap akhir barulah terjadi hubungan yang kuat dan saling memberi keuntungan antara perusahaan dengan konsumen. Pada tahap ini pula konsumen berani menolak produk atau jasa dari perusahaan lain.

\section{KESIMPULAN}

Berdasarkan hasil penelitian yang telah diuraikan maka dapat ditarik kesimpulan sebagai berikut:
Kualitas pelayanan dan kualitas produk dipandang sebagai salah satu komponen yang perlu diwujudkan oleh perusahaan, karena memiliki pengaruh untuk mendatangkan konsumen baru dan dapat mengurangi kemungkinan pelanggan lama untuk berpindah ke perusahaan lain. Loyalitas pelanggan mempunyai konsekuensi motivasional, dan behavioral. Pertama motivasi untuk mencari informasi mengenai produk. Motivasi pencarian informasi merupakan fungsi dari persepsi konsumen dari manfaat dan biaya aktivitas mencari alternatif. Manfaat pencarian akan berkurang apabila konsumen memiliki sikap relative sangat positif dan mereka dapat melakukan pembelian ulang beberapa kali. Biaya pencarian bisa berupa waktu, biaya, dan ketidaknyamanan fisik serta psikologis berkaitan dengan aktivitas mencari pemasok, produk atau merek alternative. Loyalitas pelanggan berdampak pada perilaku gethok tular (word-of-mouth behavior) terutama bila konsumen merasakan pengalaman emosional yang signifikan. Pelanggan yang loyal cenderung bersedia menceritakan pengalaman positifnya kepada orang lain.

\section{DAFTAR PUSTAKA}

Berry, L.L; Parasuraman, A; and Zeithaml, V. A. (1988), "The Service Quality Puzzle," Business Horizons, Vol.31 No.5, pp. 35-43.

Chaudhuri,A, and Holbrook, M., 2001 The chain of effect from brand Trust and Brand Affect To Brand Performance: The Role of 
Brand Loyalty Journal of Marketing, Vol.65, No.2, April pp.99-113

Dharmmesta, Basu S. (1999), "Loyalitas Pelanggan: Sebuah Kajian Konseptual Sebagai Panduan Bagi Peneliti," Jurnal Ekonomi dan Bisnis Indonesia, 14(3):73-88.

Dick, A. S. and Basu. (1994), "Customer Loyalty: Toward an Integrated Conceptual Framework," Journal of the Academy of Marketing Science, Vol. 22 No.2 (Spring), pp.99-113.

Ghozali, Imam, 2005, Aplikasi analisis dengan Program SPSS, Badan Penerbit Universitas Diponegoro, Semarang.

Karsono (2007), Peran Variabel Citra Perusahaan, Kepercayaan dan Biaya Perpindahan yang memediasi pengaruh Kualitas pelayanan Terhadap Loyalitas pelanggan, Jurnal Bisnis dan Manajemen Vol.1 No.1. hal 93110.

Kotler, P. (2009), Marketing Management, $11^{\text {th }}$ ed. UpperSaddle River, NJ: Pearson Education, Inc.

Kotler, Philip dan Gary Amstrong. (2008), Prinsip-Prinsip Pemasaran Edisi 12, Jilid I. Jakarta Erlangga.

Kotler, Philip, dan Kevin Lane Keller. (2007), Manajemen Pemasaran. Jilid I ed 12. PT. Indeks. Jakarta

Lupiyoadi, Rambat (2001), Perilaku Konsumen, Jakarta salemba Empat

Nuraini, (2007), Analisis Pengaruh Kualitas Prodk, Kualitas Pelayanan, Desain Produk, Harga dan Kepercayaan Terhadap Loyalitas Konsumen (Studi Pada
Optik Salfar), Jurnal Riset Ekonomi dan Manajemen

Riduwan. (2004), Metode dan Teknik Menyusun Thesis. Bandung: Penerbit Alfabeta.

Singgih Santoso dan Tjiptono, (2001). Riset Pemasaran Konsep dan Aplikasi dengan SPSS. Elex Media Komputindo , Jakarta.

Sugiyono, (2010), Metode Penelitian Bisnis Alfabeta, Bandung

Susilawati,(2007) "Analisis Pengaruh Kualitas Produk dan Pelayanan Terhadap Loyalitas Pelanggan", Universitas Islam Negeri Syarif Hidayatullah Jakarta,

Tjiptono, F. (2004), Pemasaran Jasa. Malang: Penerbit Bayumedia Publishing, Jawa Timur, Indonesia

Tjiptono, F. (2008), Pemasaran Jasa. Malang: Penerbit Bayumedia Publishing, Jawa Timur, Indonesia.

|Yayuk (2017), Analisis pengaruh |Kualitas produk dan kualitas pelayanan Terhadap loyalitas pelanggan Ksrtu Indosat IM3 pada Mahasiswa Fakultas Ekonomi Universitas Muslim Nusantara Al Washliyah, Jurnal Kultura Vol. 18 No. 1

Zeithaml, Valarie A; Berry, L. L; \& Parasuraman, A. (1996), "The Behavioral Consequences of Service Quality," Journal of Marketing, Vol. 60 (April), pp. 31- 46.

Zeithmal, Valarie A. and Bitner, Mary Jo. (2000), Service Marketing: Integrating Customer Focus Across the Firm, $2^{\text {th }}$ ed. Boston, McGraw-Hill Companies. 